\title{
Dimensi Aksiologis Pendidikan Islam
}

\author{
Nasrullah \\ STIBA Darul Ulum Banyuanyar Pamekasan / anastaciou88@gmail.com \\ Jaftiyatur Rohaniyah \\ Universitas Islam Madura / javetien@gmail.com \\ Abdullah Hanani \\ STIBA Darul Ulum Banyuanyar Pamekasan / al.irfanstiba@gmail.com
}

Article History:

Received: September 13, 2021

Revised: September 23, 2021

Accepted: October 1, 2021

Published: Oktober 10, 2021

https://doi.org/10.36835/alirf

an.v4i2.4999

Keywords:

Axiology, ethic, aesthetic, Islamic education
Abstract: Axiology is a theory about a value, benefit or everything that is known. Axiology divided into two parts, namely ethic and aesthetic. The ethics are divided into two parts, the first is descriptive ethics and the second is normative ethics, as well as Aesthetics, there are two parts of Aesthetics, the first is Descriptive Aesthetics and the second is Normative Aesthetics. While the source of value has two parts, namely, divine values and Inaniyah values. Characteristics and value levels are also divided into two, namely objective or subjective values and absolute or changing values. In the essence of value, there are important points such as: the value of life, the value of enjoyment, the value of usability, the value of intellectuals, the value of ethics, the value of aesthetics, and the value of religion. Islamic education has a goal, namely to make students as human beings who develop towards a better and become ethical human beings and have a personality that is in accordance with Islamic teachings, both in terms of spiritual, scientific, scientific, both individually and collectively. Values are closely related to Islamic education because Islamic education is a process of achieving perfection in terms of the ability of students in accordance with Islamic teachings.

Abstrak: Aksiologi merupakan teori tentang sebuah nilai, manfaat, atau segala hal yang diketahui. Aksiologi terbagi mejadi dua, yaitu etika dan estetika. Adapun Etika terbagi dua yang pertama Etika Deskriptif dan yang kedua Etika Normatif, begitupun dengan Estetika, Estetika Deskriptif dan Estetika Normatif. Sedangkan Sumber nilai ada dua bagian, yaitu, nilai ilahiyah dan nilai Inaniyah. Karakteristik dan tingkatan nilai juga dibagi mejadi dua yaitu nilai objektif atau subjektif dan Nilai absolute atau 
berubah. Dalam hakikat nilai terdapat poin-poin penting seperti: Nilai kehiidupan, Nilai keniikmatan, Nilai kegunaan, Nilai Intelektual, Nilai Etika, Nilai Estetika, Nilai Religius. Pendidikan Islam memiliki tujuan yaitu menjadikan peserta didik sebagai manusia yang berkembang kearah yang lebih baik serta menjadi manusia yang beretika dan mempunyai kepribadian yang sesuai dengan ajaran islam. Baik dari segi spiritual, ilmiah, keilmuan, baik secara individu maupun secara kolektif. Nilai sangat berhubungan dengan pendidikan islam karena pendidikan islam adalah suatu proses pencapaian kesempurnaan dalam hal kemampuan peserta didik sesuai dengan ajaran islam.

\section{Pendahuluan}

Islam merupakan sebuah agama yang menganjurkan manusia untuk menjadikan manusia yang berilmu. Al-Quran pandangan bahwa Pendidikan merupakan perihal yang paling utama untuk membangun serta memperbaiki manusia di bumi ini. Sebuah fokus lain dari islam dengan pendidikan adalah persepsi yang juga tidak sama agar tercipta konsep yang bisa dimengerti secara keseluruhan oleh semua golongan, terutamanya bagi pendidik dan peserta didik.

Rasionalitas dan Pragmatisme dijadikan dasar logika oleh pendidikan pada umumnya, maka akan terjadi perbedaan dengan dasar logika pada pendidikan islam. Hal ini mempengaruhi terhadap pelaksanaan pembelajaran, karena yang ditekankan dalam pendidikan islam adalah penanaman iman dan takwa. Dalam perbedaan itulah kita diharuskan tahu serta memahami dasar serta konsep pendidikan islam yang sudah diketahui memiliki perbedaan didalamnya dengan pendidikan pada umumnya.

Sampai akhirnya, semua aspek masyarakat turut andil dan terlibat serta berperan aktif didalam pengembangan semua tingkatan pendidikan mulai dari yang terendah seperti tingkatan dasar hingga tingkat atas atau biasa kita sebut tingkat universitas mengerti secara clear akan pondasi pendidikan islam. Jika kita membahas tentang ketiga dimensi seperti, ontologi, epistimologi, dan aksiologinya tentu secara umum memiliki konsep yang sama dengan konsep pendidikan. Hal ini justru akan menghasilkan perberbedaan jika Islam dimasukkan kedalam bagian-bagiannya. Ketiga dimensi seperti ontologi, epistimologi dan aksiologi dalam pendidikan umum, tidak sama dengan ontologi, epistimologi, dan aksiologi dalam berbagai macam kajian 
lainnya. Namun dalam artikel ini, penulis akan lebih fokus membahas dimensi aksiologi sehingga nantinya penulis bisa menggambarkan kepada pembaca bagaimana pendidikan islam hingga secara umum bisa dikatakan berbeda dengan pendidikan dalam kajian tersebut.

Ketika manusia menjadi subjek utama dalam usaha mempelajari makna pendidikan islam secara keseluruhan, kita disarankan fokus pada satu kajian saja, melainkan harus ada berbagai macam kajian akan hal ini. Dalam pendidikan, ketika kita berhadapan dengan manusia, akan banyak masalah yang dapat kita temui, seperti permasalahan pokok dalam kehidupan manusia.Namun kemudian, ketika manusia memasuki alam berfikir filsafat, pendidikan akan menjadi pertanyaan besar bagi manusia.

\section{Pembahasan}

\section{Definisi Istilah}

Aksiologi dilihat dari definisi secera etimologis berasal dari bahasa yunani yaitu, Aksio yang berarti nilai dan logis yang berarti teori yang berarti aksiologi adalah teori nilai. Menurut Encyclopedia of philosophy, aksiologi artinya sama seperti value atau valuation (nilai dan penilaian). Jadi Aksiologi merupakan teori tentang sebuah nilai, manfaat, atau segala hal. Dalam pendidikan, teori nilai dalam hal ini memiliki kaitan dengan nilai yang yang diinginkan oleh manusia yang pada akhirnya dapat dipergunakan sebagai dasar hidupnya.

Bamel berpendapat bahwa aksiologi memiliki tiga bagian, yaitu: (1) Moral Conduct yang berupa tindakan moralitas dan melahirkan kedisiplinan Etika,: (2) Esthetic expression, merupakan sebuah ekspresi keindahan yang melahirkan kedisiplinan estetika.; dan (3) Socio-political life yang merupakan sebuah kehidupan sosial-politik dan melahirkan filsafat sosial politik. ${ }^{1}$

Dimensi aksiologi membicarakan khusus tentang sebuah nilai yang berkaitan dengan ilmu, hingga muncul petanyaan, apakah ilmu itu bebas nilai atau terkait nilai. ${ }^{2}$ Nilai juga dapat dilihat sebagai kata benda yang konkrit. Salah satu contoh adalah ketika kita berbicara serta membahas sesuatu yang berkaitan dengan nilai-nilai, maka

1 I Dewa Gede Dkk, Filsafat Ilmu (Dari Pohon Pengetahuan Sampai Karakter Keilmuan Ilmu Hukum) (Malang: Madani, 2014). 42

${ }^{2}$ Haidar Putra Daulay, Pendidikan Islam Dalam Perspektif Filsafat (Jakarta: Kencana Prenada Media Group, 2014). 66 
hal itu sering merujuk kepada sesuatu yang bernilai. Sama halnya penilaian pada ruang lingkup prestasi yang dijadikan sebagai alat bukti yang nyata diperoleh dengan kerja keras.

Pembahasan tentang aksiologi memilik hubungan erat dengan persoalan nilai pada kegunaan suatu ilmu, dikarenakan pada dasarnya keilmuan berada pada ruang lingkup nilai. pada tahapan tertentu yang terkadang ilmu harus sesuai dengan nilai kebudayaan serta moral suatu masyarakat sehingga masyarakat dapat merasakan nilai kegunaan ilmu dalam upaya meningkatkan kesejahteraan dan bukan sebaliknya malah memunculkan sebuah masalah. ${ }^{3}$ Perlunya penyesuaian nilai dengan keilmuan, akhlak serta moral, budaya dalam sebuah pendidikan islam, karena akan terjadi ketimpangan ketika tidak adanya keseimbangan didalamnya, termasuk dalam meningkatkan kualitas dan kesejahteraan manusia.

Aksiologi menurut Suriasumantri adalah sebuah teori tentang nilai yang berhubungan dari segi kegunaan, dan model pengetahuan yang didapat, untuk kemudian digunakan dalam setiap aspek pendidikan. ${ }^{4}$ Dalam bagian ini, ilmu bisa digunakan sebagai penyalur dalam mengembangkan kualitas hidup manusia, dan kelestarian atau keseimbangan alam. Wibisono memberikan tanggapan penjelasan dari pemikiran Suriasumantri ini, aksiologi menurut Wibisono adalah suatu nilai dapat dijadikan sebagai tolak urkur kebenaran moral dan etika sebagai dasar yang normatif pada sebuah research dan penggalian serta pengaplikasian ilmu. ${ }^{5}$ Itu artinya segala sesuatu dilakukan oleh setiap individu masyarakat baik dari segi etika maupun moral akan menjadi tolak ukur pembenaran atas sikap mereka, terutama dalam mempraktekkan sebuah ilmu nantinya.

Pada persoalan diatas dapat disimpulkan bahwa adanya keterikatan penting antara kebudayaan dengan sebuah pendidikan dikarenakan hubungan keduanya dapat dijadikan sebagai alat untuk menciptakan kemajuan pada masyarakat itu sendiri.Jika diamati dari sudut pandang sosial, pewarisan berbagai nilai kebudayaan dalam sebuah pendidikan kepada generasi muda untuk menjadikan generasi tersebut sebagai generasi yang memiliki nilai-nilai yang terpelihara yang kemudian bertujuan semakin baik untuk kedepannya. Yang dimaksud diatas adalah seseorang atau

\footnotetext{
${ }^{3}$ Burhanuddin Salam, Logika Materil Filsafat Ilmu Pengetahuan (Jakarta: Rineka Cipta, 1997). 168

4 Surajiyo, Filsafat Ilmu Dan Perkembangannya Di Indonesia (Jakarta: Bumi Aksara, 2007). 152

${ }^{5}$ Jujun S. Suriasumantri, Filsafat Ilmu Sebuah Pengantar Populer (Jakarta: Pustaka Sinar Harapan,
} 1990). 234 
sekelompok orang akan merasa dirinya sudah melakukan kebaikan atau sudah melakukan hal-hal yang dibenarkan agamanya ketika dia sudah merasa mematuhi nilai-nilai ajaran agama. ${ }^{6}$

Jadi, nilai-nilai dalam dunia pendidikan sangatlah berpengaruh, tidak hanya berpengaruh pada aspek sosial kemasyarakatan saja. Namun nilai-nilai tersebut diharapkan nantinya akan menjadi tolak ukur keislaman sekaligus sebagai pedoman diri dalam meningkatkan keshalihan, ketaatan, serta kepatuhan terhadap apapun yang telah diperintahkan oleh Tuhan yang Maha Esa.

Menurut penulis buku dimensi kajian filsafat ilmu, aksiologi memiliki muatan pemikiran tinggi tentang permasalahan nilai dihadapan Allah SWT. Aksiologi juga mengandung pengertian yang luas dari pada etika atau higher values of life ( nilai kehidupan yang bertaraf tinggi ). ${ }^{7}$ Secara universal, seseorang menimbang nilai dengan takaran baik atau buruk (etika), indah atau jelek (estetika). ${ }^{8}$ Segala aspek yang terkandung didalam sebuah nilai memiliki tujuan yang sama, yaitu untuk membedakan baik buruknya segala sesuatu yang kemudian bertujuan untuk mendapatkan penyelesaian terhadapnya. Sebagai cabang ilmu filsafat jenis nilai dalam aksiologi dibagi menjadi dua, yaitu etika dan estetika

Etika bila dilihat dari etimologi berasal dari kata yunani, yakni ethos yang berarti watak kesusilaan atau adat. Secara terminologi, etika merupakan salah satu cabang filsafat yang membahas tentang bentuk atau pola perilaku atau perbuatan manusia yang berkaitan dengan perilaku baik atau perilaku buruk. Kemudian penilaian baik atau buruk adalah mengenai perilaku manusia yang memiliki sangkut paut dengan perbuatan, tingkah laku, gerakan, perkataan dan sebagainya. Sedangkan yang sukar untuk dinilai adalah seperti halnya motif, watak dan suara hati.

Pola tingkah laku bisa dinilai dengan kesadaran, sedangkan perilaku ataupun perbuatan tanpa kesadaran tidak dapat dinilai baik-buruknya. ${ }^{9}$ Jadi, ada hal-hal tertentu yang membuat nilai-nilai tersebut berlaku, salah satunya adalah, manusia tersebut harus mampu berfikir,berfikir dalam artian mampu membedakan baik buruknya segala sesuatu, bergerak, melakukan segala sesuatu dengan penuh

${ }^{6}$ Mahfud, Mengenal Ontologi, Epistemologi, Aksiologi Dalam Pendidikan Islam (Bawean: STAI Hasan al-Jufri, n.d.). 94

7 A. Susanto, Filsafat Ilmu (Suatu Kajian Daam Dimensi Ontologis, Epistimologis, Dan Aksiologis) (Jakarta: Bumi Aksara, 2016). 116

8 Siswanto, Filsafat Dan Pemikiran Pendidikan Islam (Surabaya: Pena Salsabila, 2017). 85

9 Surajiyo, Ilmu Filsafat Suatu Pengantar (Jakarta: Bumi Aksara, 2014). 88 
kesadaran, karena jika manusia hanya dapat berperilaku tanpa dibarengi dengan kesadaran, maka yang mereka lakukan tidak dapat ternilai.

Etika juga dapat dipandang sesuatu yang memiliki keterikatan dengan nilai atau memiliki relevansi etis, Seperti halnya Agama, merupakan sesuatu yang tidak memiliki perbedaan dengan hukum, adat kebiasaan memiliki unsur etis atau mengandung pandangan-pandangan tentang apa yang dianggap baik atau dianggap buruk. Dikatakan etika ketika berbagai aspek memiliki keterikatan dengan nilai serta relevansi dengan etis.

Salah satu cabang filsafat tertua adalah etika. Etika sudah menjadi pembahasan yang menarik setidaknya mulai dari zaman Socrates, yang pada saat itu mempersoalkan masalah kebaikan, keutamaan dan keadilan. ${ }^{10}$ Hakikatnya etika mengamati kenyataan moral secara kritis. Etika disini tidak memberikan pengajaran melainkan memeriksa habitual, value, dan pandangan-pandangan moral secara kritis. ${ }^{11}$ Etika seringkali disamakan dengan akhlak serta moral, bahkan sampai ada ulama yang berpendapat bahwa akhlak adalah etika dalam Islam. ${ }^{12}$ Etika Islam memiliki arti sebuah gerak-gerik manusia yang berwujud dalam bentuk perilaku, perkataan dan pola pikir yang memiliki sifat membangun, tidak merusak lingkungan, dan tidak merusak tatanan sosial budaya serta tidak berlawanan dengan yang diajarkan agama, namun senantiasa berlandasan dengan Qur'an dan Hadist. ${ }^{13}$

Berbagai aspek keadilan, kebaikan, keutamaan serta keadilan sudah menjadi pembahasan dalam cabang flsafat tertua sampai pada saat ini. Pada dasarnya etika tidak terlalu fokus pada sistem pembelajaran melainkan lebih fokus kepada praktek yang sudah menjadi kebiasaan pada Nilai, Norma, dan pandangan moral secara kritis. Pada umumnya, dalam pendidikan islam etika serta moral sering dianggap sama, bahkan tidak jarang sampai ada ulama yang beranggapan bahwa moral adalah etika islam. Dalam pengertiannya etika islam adalah segala bentuk perilaku manusia, baik dari cara berfikir, cara mereka berbicara, serta kepemilikan pola fikir yang bersifat membangun serta berlandaskan kepada Qur'an serta hadist sebagai pedoman hidup manusia.

\footnotetext{
${ }_{10}$ Aceng Rachmat, Filsafat Ilmu Lanjutan (Jakarta: Kencana Prenada Media Group, 2011). 156-157

11 Toto Suharto, Filsafat Pendidikan Islam (Menguatkan Epistimologi Islam Dalam Pendidikan) (Yogyakarta: Ar-Ruzz Media, 2014). 89

12 Istighfaratur Rohmaniyah, Pendidikan Etika, Konsep Jiwa Dan Etika Perspektif Ibnu Miskawaih Dalam Kontribusinya Dalam Pendidikan Islam (Malang: UIN Maliki Press, 2010). 57 ${ }^{13}$ Ibid. 7
} 
Akhlak islami yang telah dijelaskan diatas memiliki arti yang berbeda. Perbedaanya dapat dilihat utamanya dari berbagai refrensi. Baik menurut akhlak merupakan segala hal yang bermanfaat, dan berguna, serta sesuai dengan nilai-nilai agama, yang nantinya akan bermanfaat untuk diri sendiri dan orang sekitar.

Perilaku buruk merupakan hal yang tidak memiliki daya guna dan tidak sesuai dengan nilai budaya masyarakat serta agama, yang nantinya menimbulkan kerugian buat diri sendiri dan masyarakat, yang menenentukkan baik buruknya perilaku (akhlak). Perilaku atau perbuatan manusia didalam ajaran agama islam adalah alQur'an yang diterangkan oleh Rasulullah saw dalam sunnah beliau kini bisa ditemukan dalam berbagi kitab hadis. Sedangkan yang menjadi tolak ukur baik atau buruk sebuah perilaku dalam etika dan moral adalah adat istiadat serta pikiran manusia dalam lingkungan masyarakat di suatu tempat pada suatu saat nanti.

Berdasarkan berbagai macam sumber, akhlak islami mempunyai sifat kekal dan berlaku selamanya, sedangkan etika dan moral memiliki jangka waktu tertentu disuatu tempat tertentu. Konsekuensi akhlak dalam islam bersifat mutlak, sedangkan moral dan etika bersifat relatif (nisbi). Perbedaan penafsiran semacam ini harus dipahami agar nantinya kita bisa membedakan sifat dan isi akhlak serta moral dan etika. Meskipun sejatinya anggapan masyarakat pada ketiga istilah itu disinonimkan serta digunakan untuk menunjukan sesuatu yang baik atau buruk, kendati istilah akhlak terlihat semakin lama semakin terdesak.14

Persamaan anggapan pada ketiga point penting diatas, yaitu akhlak, moral serta etika sangat mudah untuk dipahami karena hal tersebut memiliki tujuan yang sama, serta berada dalam konteks yang sama, tidak lain untuk berperilaku sesuai dengan pedoman umat manusia, yaitu Al-Qur'an dan sebagai penjelasnya adalah AsSunnah. Akan tetapi terdapat perbedaan waktu masa berlaku akhlak yang semakin hari semakin tidak diperhitungkan.

\section{Etika dalam Dimensi Aksiologi}

1. Etika Deskriptif

Etika deskriptif adalah penggambaran terhadap prilaku moral dalam segi universal (umum) terhadap kebiasaan, penilaian baik buruk perilaku, serta tindakan apa saja yang diperboleh atau tidak diperbolehkan. Etika deskriptif bersifat netral

14 Mohammad Daud Ali, Pendidikan Agama Islam (Jakarta: Rajawali Press, 2013). 356 
karena etika ini memahami serta mempelajari moral pada setiap diri individu, kebudayaan, dan sub cultur tertentu. Jadi dapat di ambil kesimpulan bahwa etika deskriptif merupakan etika yang membahas mengenai fakta yang nyata, sesuai dengan keadaan yang ada. Yaitu tentang moral dan akhlak manusia sebagai sebuah realita yang berkaitan dengan situasi atau kondisi yang sangat berkaitan erat dengan kebudayaan. ${ }^{15}$ Ia membahas tentang fakta dan penghayatan terhadap nilai tanpa menilai masyarakat tentang sikap dan perilaku seseorang dalam menjalani kehidupan, serta kondisi yang memungkinkan manusia untuk berperilaku secara pantas yang memilki makna baik atau buruk dalam bersikap.

Etika pada dasarnya mendeskripsikan perilaku dari berbagai aspek, baik tradisi, habit, serta culture. Etika Deskriptif pada dasarnya lebih fokus dalam mencari tahu tentang tradisi yang mempermasalahkan suatu masalah yang sama. Sebagai contoh: penggambaran mengenai suatu adat mengayau kepala pada suku yang primitif. Etika ini dibagi lagi menjadi dua, yang pertama adalah sejarah moral yang meneliti tentang cita-cita dan norma yang berlaku pada waktu tertentu pada kehidupan manusia atau pada sebuah lingkup besar yang mencakup fenomena moral yang ada. ${ }^{16}$ Etika Deskriptif lebih konsen kepada pendeskripsian perbuatan dari berbagai aspek serta mencari tahu bagaimana tradisi yang mempesoalkan persoalan yang sama.

\section{Etika Normatif}

Etika normatif boleh disebut juga dengan filsafat moral (moral phylosophy) atau etika filsafat (phylosophical ethics). ${ }^{17}$ Etika ini fokus kepada pendiriannya atas norma. Etika bisa menyoal masalah norma yang didapatkan seseorang atau komponen masyarakat dengan cara kritis. Etika dapat menyoal apakah norma itu benar atau tidak. Selain itu, Etika Normatif memberikan petunjuk dalam setiap pengambilan keputusan yang didalamnya berkaitan dengan baik atau buruk. Berikut adalah macam-macam norma didalam ilmu filsafat :

15 “Pengertian-Aksiologi-Aspek-Menurut-Para-Ahli," accessed September 13, 2021, https:/ / pendidikan.co.id.

16 Ibid.

17 Totok Wahyu Abadi, “Aksiologi: Antara Etika, Moral,” Kanal (n.d.), https://ojs.umsida.ac.id?index.php/kanal. 


\section{Norma sopan santun}

Norma ini berkaitan dengan sifat lahiriah manusia, meskipun sifat ini bisa mengutarakan sikap hati karena memiliki moral yang berkualitas. Orang yang menyalahi norma kesopanan dikarenakan tidak tahu tata krama didaerah tersebut atau dituntut oleh situasi tidak dikatakan melanggar norma moral namun akan dikatakan sebagai norma sopan santun. Oleh sebab itu, diharapkan pada setiap komponen masyarakat untuk bekerja sama dalam menjaga sikap sopan santun dimanapun dan kapanpun, dalam keadaan apapun.

\section{Norma hukum}

Pada norma hukum sangatlah dituntut tegas oleh masyarakat. Hal ini dianggap sangat perlu demi keselamatan dan kesejahteraan umum, sehingga Norma hukum merupakan norma yang tidak dibiarkan untuk dilanggar. Pada norma hukum tidak menjadi sebuah tolak ukur baik buruknya seseorang sebagai manusia melainkan untuk menjamin ketertiban umum. Jadi, bagi yang melanggar norma hukum pasti dikenakan sanksi meskipun norma hukum tidak bisa juga disamakan dengan norma moral. Hal tersebut bisa dikatakan bahwa norma hukum akan menjadi tolak ukur penilaian terhadap perilaku manusia sekaligus sebagai hakim dalam setiap pelanggaran yang terjadi pada masyarakat demi tercapainya sebuah keadilan serta kesejahteraan.

\section{Norma moral}

Norma moral dijadikan oleh masyarakat sebagai tolak ukur oleh masyarakat sebagai pengukur kebaikan seseorang dan dengan moral kita dapat dinilai. Oleh sebab itu, penilaian tentang moral harus selalu berbobot. Manusia tidak dapat dilihat selain dari segi kemanusiaan, entah sebagai warga negara yang taat atau sebagai warga yang tidak taat. Hal hal inilah yang akan menjadi permasalahan moral. ${ }^{18}$

Penyalah gunaan narkoba adalah salah satu contoh penerapan etika normatif. Perilaku ini harus dihindari karena bisa merusak keshatan dan membahayakan diri sendiri. Perilaku lain yang perlu kita hindari adalah Aborsi, karena hal ini perbuatan yang dapat menghilangkan nyawa orang lain yang tidak berdosa, serta menyiksa diri sendiri. Berikutnya perilaku yang perlu kita hindari adalah Kebiasaan meminum minuman keras, karena bisa mengakibatkan hilangnya kesadaran manusia. Perilaku

18 Surajiyo, Ilmu Filsafat Suatu Pengantar. 91 
yang perlu kita hindari adalah kebiasaan prostitusi, karena bertentangan dengan martabat serta harga diri seorang manusia.

Selanjutnya penulis akan membahas tentang nilai estetika dan bagianbagiannya dalam filsafat pendidikan islam :

\section{Nilai Estetika (Esthetic Expression) atau Ekspresi Keindahan}

Estetika merupakan salah satu cabang dari filsafat yang pembahasannya tentang keindahan. Kata Estetika berasal dari kata Yunani yaitu aesthetis atau pengamatan. Fokus utama estetika ialah pengalaman akan keindahan. Hakikat dari keindahan itu sendiri seperti halnya keindahan jasmani dan rohani, keindahan alam dan seni, diikuti oleh emosi manusia sebagai sebuah reaksi terhadap sesuatu yang indah, agung, tragis, bagus, dan lain-lain merupakan suatu hal yang dicari didalam Estetika. Estetika adalah bagian dari aksiologi yang membicarakan tentang permasalahan, pertanyaan, dan isuisu tentang keindahan, ruang lingkup, nilai, experience atau pengalaman, serta persoalan estetika pada lingkup manusia. ${ }^{19}$

Jadi Estetika ada dua, yang pertama adalah Estetika Deskriptif dan yang kedua Estetika Normatif. Estetika deskriptif memberikan deskripsi dan melukiskan fenomena keindahan. Sedangkan etika normatif mempermalahkan serta menyelidiki hakikat, dasar dan ukuran pengalaman keindahan. Estetika merupakan suatu hal yang relatif, setiap orang memiliki penilaian serta pemikiran terhadap sebuah keindahan yang berbeda-beda dalam hal ini, letak sebuah keindahan tidak hanya pada seseorang yang memiliki alis tebal, kulit putih dan hidung yang mancung.

\section{Karakteristik dan Tingkatan Nilai}

Berkaitan dengan teori nilai, ada dua karakteristik nilai, yaitu:

1. Nilai Subjektif dan Nilai Objektif

Nilai dapat dikatakan subjektif jikalau keaktifan serta makna dan kebenarannya bergantung kepada reaksi subjek yang melakukan penilain tanpa menimbang apakah hal tersebut bersifat psikis atau fisik. ${ }^{20}$ Sedangkan, nilai dapat dikatakan objektif jika hal tersebut tidak berpedoman pada subjek atau kesadaran penilai dan begitupun sebalikannya,

2. Nilai absolute

19 Elok Setia Ningsih, “Estetika Dan Pendidikan” (IAIN Kediri, 2014).

20 "Kompas," accessed September 13, 2021, www.kompasiana.com. 
Sebuah nilai bisa dikatakan abadi jika nilai yang berlaku pada saat ini sudah berlaku mulai dari masa lalu dan akan berlaku seterusnya, teruntuk siapapun, dimanapun, tanpa mempermasalahkan ras ataupun tingkatan sosial.

Kaum idealis berpendapat secara yakin tentang tingkat-tingkat nilai yang mana nilai spiritual itu lebih tinggi dari pada nilai non spiritual. ${ }^{21}$ Karena pada dasarnya, nilai spiritual melahirkan sifat atau perilaku yang santun baik secara nurani hingga akhirnya membawa dampak positif terhadap aspek jasmani seseorang.

\section{Hakikat Nilai}

Aksiologi ialah ilmu yang mempelajari tentang nilai yang merupakan suatu hal yang berharga. Nilai yang dijelaskan diatas terbagi menjadi dua, yaitu nilai jasmani dan rohani. Nilai pertama adalah Jasmani yang terdiri atas nilai hidup, nilai nikmat, dan nilai guna. Nilai kedua adalah Rohani terdiri atas nilai intelektual, nilai estetika, nilai etika, dan nilai religi.

Beberapa nilai di atas disusun sebagai berikut dimulai dari dari nilai hidupnilai nikmat $\rightarrow$ nilai guna $\rightarrow$ nilai intelek $\rightarrow$ nilai etika $\rightarrow$ nilai estetika $\rightarrow$ nilai religi. Hal ini dapat dijelaskan dengan contoh dari beberapa hal yang mengandung beberapa nilai tersebut:

a. Nilai Kehidupan seperti halnya sakit-sehat, menelan-muntah.

b. Nilai Kenikmatan seperti halnya suka-duka, wangi-bau, manis-pahit.

c. Nilai Kegunaan seperti halnya Manfaat-mudarat, mengggunakan-menanggalkan.

d. Nilai intelektual seperti halnya cermat-ceroboh, cerdas-bebal.

e. Nilai estetika seperti halnya mulus-cacat, mekar-kuncup.

f. Nilai etika seperti halnya bakti-durhaka, jujur-bohong.

g. Nilai religi seperti halnya mustahil-mungkin, yakin-curiga.

\section{Sumber Nilai dalam Kehidupan Manusia}

A. Susanto memiliki pandangan tentang hubungan antara pendekatan etika dan estetika dengan pendidikan islam diwajibkan objek kajian serta susunan dan rangkain proses yang dilakukan mempunyai nilai keagamaan (ketuhanan). Pendekatan yang seperti ini sebenarnya memiliki fungsi untuk kemudian menjadi

${ }^{21}$ Agus Salim, “Kajian Tentang Aksiologi Pendidikan Islam,” last modified 2015, https:/ / isabelaagus.com 
sebuah alat kontrol yang baik terutama dalam melihat makna, tentang sisi kesempurnaan suatu konsep pendidikan yang telah ditwarkan pada manusia. ${ }^{22}$

Terdapat dua sumber nilai yang berlaku pada sosial hidup manusia, yaitu:

1. Nilai Ilahiyah

Nilai ilahiyah ialah suatu nilai yang diturunkan oleh Allah kepada Rasul -Nya yang berbentuk iman, taqwa dan adil yang diabadikan dalam bentuk Wahyu. Nilai ini memiliki sifat kekal dan tidak akan pernah berubah.

Nilai ilahiyah terbagi kedalam dua bagian, yaitu nilai yang berasal pada sifatsifat Allah dengan jumlah sembilan yang diwadahkan pada Asmaul Husna, ialah nama-nama indah. Hingga akhirnya nilai tersebut yang memiliki potensi sebagai dasar manusia yang dapat dikatakan sebagai fitrah. Dan yang kedua yaitu nilai yang berupa Qur'aniyah maupun kauniyah, yaitu nilai yang berasal dari hukum dan ketentuan Allah

Spiritual keilahian merupakan nilai yang erat dengan pendidikan, oleh karena itu hakikat pendidikan merupakan masalah bagi manusia dalam fitrahnya sebagai makhluk ciptaan Tuhan. Dilihat dari sifat ini, manusia bisa berinovasi dalam melakukan perubahan dan pengembangan atas dirinya sebagai manusia dengan melewati segala sistematika kegiatan pendidikan yang memiliki hakikat memanusiakan manusia sebagai makhluk ciptaan Allah.

Nilai pada umumnya memiliki prinsip yang kekal (extend) dalam perspektif islam yang tertuang salah satu dalam firman Allah SWT:

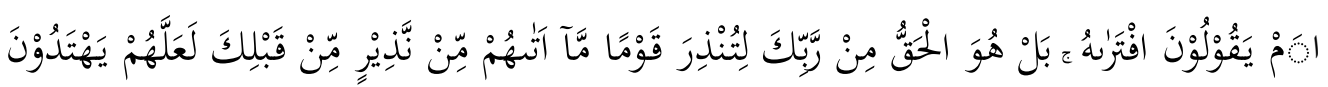

Artinya: “Tetapi kenapa mereka (orang kafir) mengatakan: "Dia Muhammad mengada-ngada." Pada Hakikatnya, Al-Quran itu adalah kebenaran dari Tuhanmu agar kamu memberi peringatan pada kaum yang belum datang kepada mereka orang yang memberi peringatan sebelum kamu; Semoga mereka mendapatkan petunjuk (Qs. As-Sajadah : 3).

2. Nilai Insaniyah

Nilai Insaniyah lahir dari peradaban manusia, serta berkembang dari peradaban manusia. Nilai Insaniyah memiliki sifat yang dinamis, sedangkan

22 Indah Husnul Khotimah, "Dimensi Aksiologis Pendidikan Islam," accessed September 27, 2021, https://www.researchgate.net/publication/329528105. 
kebenarannya relatif nisbi yang memiliki batas pada ruang dan waktu. Nilai ini kemudian melembaga menjadi tradisi yang kemudian menjadi warisan turunansehingga mengakibatkan keterikatan serta hubungan dengan pendukungnya yang mencakup anggota dalam sebuah masyarakat.

Pendidikan dan pembelajaran agama pada umumnya memiliki visi dan misi yang sama, dengan satu tujuan tidak lain untuk mengembangkan potensi anak didik, khususnya dalam segi akhlak sesuai dengan kerangka normatif agama serta bisa mengubah pola sikap tiap individu secara universal dan tentunya dengan waktu yang cukup lama. Oleh karenanya keberhasilan sebuah pembelajaran agama ialah ketika siswa mampu berada dalam ranah syahadah (benar) untuk memahami kehidupan yang tersinari oleh nilai Ilahiyah dan Insaniyah berlandaskan pendidikan agama yang diperoleh. Setiap pelaksanaan nilai tersebut yang sudah dijelaskan diatas harusnya tidak berupa paksaan dari luar melainkan memahami bagaimana cara yang pantas dan lembut untuk mengetuk pintu hati siswa.

3. Nilai Dan Tujuan Pendidikan Islam

Terdapat dua istilah yang sering digunakan untuk nilai didalam bahasa asing seperti bahasa arab, yaitu fadhilah dan qiimah, fadhilah disini sering dipergunakan dengan keterikatannya dengan nilai-nilai moral, sedangkan qiimah digunakan dalam kaitannya dengan ekonomi.

Kegiatan yang mulia seperti pendidikan disini mempunyai nilai-nilai kebagian bagi kemanusiaan, nyatanya dalam segala kegiatannya pendidikan senantiasa mempunyai tujuan untuk menhasilkan manusia sebagai makhluk yang memiliki nilai moral yang tinggi. Pada fokus Pendidikan Islam adalah nilai moral yang masuk kedalam bagian integral dalam serak usaha dunia pendidikan yang sudah terstruktur secara formalitas tidak hanya terdapat pada tujuan institusional pendidikan saja, akan tetapi diharapkan bisa menjalin hubungan erat dalam setiap proses dan kegiatannya.

Moral atau akhlak ialah suatu nilai atau norma yang dijadikan manusia sebagai pedoman dalam menjaga dan mengatur setiap pola perilakunya. Dalam pandangan islam, nilai dibagi menjadi dua bagian yaitu tetap dan tidak tetap. Pertama yaitu nilai mutlaq, nilai mutlak disini memiliki arti nilai yang wajib dan telah disepakati termasuk kepada nilai yang jelas. Kedua adalah nilai muqayyad, nilai ini memiliki pengertian sebagai nilai yang fleksibel dan terlahir dan dilahirkan dari dinamika masyarakat. 
Pada dasarnya, sebuah nilai diharapkan timbul secara natural atau dengan sendirinya, ini dikarena bisa mengarah kepada sikap accepted (menerima) dan rijected (menolak) sekelompok orang kepada suatu realita hubungan subjek serta objek yang prosesnya tidak dapat dilepaskan dari pengetahuan dan wawasan subjek penentu nilai. Oleh sebab itu, nilai akan senantiasa berkembang dan melakukan revolusi sebagai bentuk perbaikan sejalan dengan habbit dan sikap mental seseorang atau suatu kelompok dalam sebuah masyarakat. Hal ini tentu memiliki keterikatan erat dengan usaha pendidikan sebagai tempat penyaluran sebuah revolusi serta bentuk attitude reparation (memperbaiki perilaku) niscaya menentukan sikap hidup masyarakat. ${ }^{23}$

Siswanto berpendapat bahwa suatu wujud nilai ideal terbentuk pada pribadi manusia yang diinginkan merupakan pengertian singkat mengenai tujuan yang ingin dicapai. Setiap nilai ideal bisa memberikan dampak dalam kehidupan manusia terutama dalam kepribadiannya. Sehingga dapat tergambar jelas dalam perbuatan manusia dalam kehidupan sehari-hari. nilai ideal yang disebut penulis dengan akhlak dapat tergambar dari bagaimana manusia bertingkah laku setiap harinya. Oleh sebab itu, jika yang kita bahas mengenai tujuan nilai-nilai pendidikan, maka nantinya kita akan mengetahui tujuan dari pendidikan itu sendiri, karena ketika kita merumuskan tujuan pendidikan islam akan kita temui nilai-nilai tersebut yang sudah tertanam dalam benak peserta didik. Begitupula ketika kita membahas mengenai tujuan pendidikan islam, maka tidak akan keluar dari konteks nilai-nilai pendidikan islam yang sudah menjadi identitas dari pendidikan islam itu sendiri.

Dari hasil pembahasan diatas, tujuan pendidikan islam berpedoman kepada nilai-nilai yang terkandung pada identitas Pendidikan Islam, seperti nilai kesosialan, nilai keilmiahan, nilai moralitas dan nilai keagamaan. Jika kita menelisik lebih jauh, pendidikan islam tentunya sudah memiliki kekuatan yang besar untuk mencapai sebuah kesempurnaan hidup.

Dalam merumuskan tujuan pendidikan islam, Siswanto lebih komprehensif mendeskripsikan bahwa dalam setiap merumuskan tujuan Pendidikan Islam harus berpatokan pada empat aspek, yaitu:

1. Tugas Pokok dan Tujuan manusia.

23 “Kompas." 
Dalam hal ini, yang dimaksud tugas pokok manusia sebagai khalifah dimuka bumi, dianjurkan untuk senantiasa beribadah dan istiqomah untuk selalu berada dijalan Allah.

2. Sifat dasar (Nature) manusia.

Sifat dasar yang dimaksud dalam sub bab ini adalah fitrah penciptaan manusia. Sebagaimana diterangkan dalam QS. Ar-rum ayat 30.

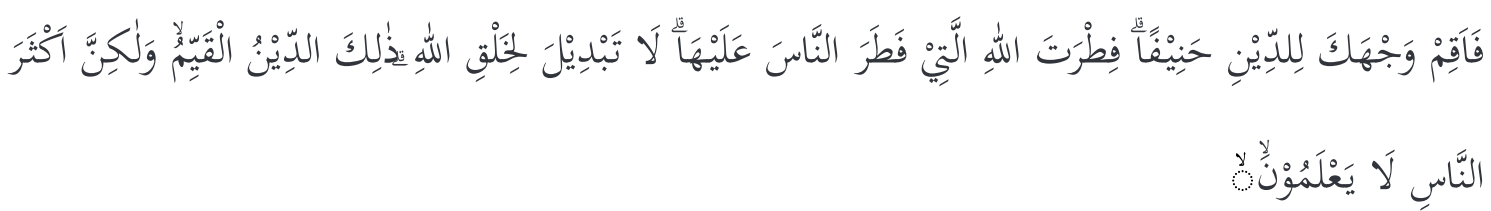

Artiinya: "Maka hadapkan wajahmu dengan lurus kepada agama Allah; (tetaplah atas) fitroh Allah yang telah menciptakan manusia menurut fitroh itu. tidak ada peubahan pada fitroh Allah. (Itulah) agama yang lurus, akan tetapi kebanyakan manusia tidak mengetahuinya" (QS. Ar-Rum: 30).

3. Tuntutan masyarakat dan zaman.

Dalam hal ini, yang dimaksud tuntutan nilai-nilai baru yang lahir karena adanya percepatan perkembangan dunia modern. ${ }^{24}$

4. Kehidupan ideal islami.

Kali ini, Siswanto memiliki pandangan yang sama denga Muzayyin Arifin yang memiliki anggapan bahwa sistem pendidikan islam harus mampu casting the balance (menyeimbangkan) antara dimensi duniawi dengan dimensi ukhrawi. The balance of (keseimbangan antara) dua dimensi tersebut digambarkan oleh Siswanto sebagai penangkal segala negatif effect (pengaruh negatif) yang mendekati pribadi muslim dalam kehidupan sehari-hari.Dari hasil penjelasan diatas, penulis berpendapat bahwa tujuan Pendidikan Islam ialah menghasilkan generasi yang beriman, berilmu serta berakhlak sesuai dengan anjuran rasulullah saw yang ditujukan semata-mata hanya kepada Allah.

\section{Memperkuat Dasar Bagi Nilai-Nilai.}

Tugas sebuah pendidikan, termasuk dalam pedidikan disekolah yang paling utama adalah menumbuhkan nilai-nilai. Dalam hal ini, ditemukan masalah utama: nilai mana yang ingin ditanamkan pada peserta didik? Pertanyaan tersebut akan

${ }^{24}$ Moh. Khorofi, “Dimensi Aksiologi Pendidikan Islam” (IAIN MADURA, n.d.). 10 
menjadi besar dalam dunia pendidikan. Sangat disesali sekali jika hal ini tidak dipahami oleh pengambil keputusan dalam sebuah pendidikan. Sedangkan, banyak kita ketahui bahwasanya nilai adalah harga. Sesuatu yang berharga akan memiliki nilai jual yang tinggi. Dapat diartikan, bahwasanya bernilai itu berharga. ${ }^{25}$

Ketika kita membahas tentang kebudayaan, hal pertama yang akan kita bahas adalah kebudayaan benar salah, dikarekan ukurannya jelas. Adapun tolak ukur utama pada kebudayaan ini adalah logika. Pada umumnya Logika memiliki sifat sama pada setiap individu. Beda halnya ketika kita berbincang-bincang, berdebat tentang budaya kedua, yaitu kebudayaan baik dan buruk. Kebudayaan baik dan buruk ini sering muncul perdebatan (sukar mencapai kata sepakat) karena ukurannya sewaktu-waktu sangat subjektif. Subjektifitas itu muncul dikarenakan penilaian terhadap kebudayaan baik-buruk mayoritas bersumber terhadap keyakinan serta perasaan. Oleh sebab itu, jika kita membahas tentang tentang kebudayaan baik dan buruk akan berpotensi polemik yang berkepanjangan.

Masyarakat hari ini sering kali membicarakan mana yang lebih baik antara budaya pada jaman orde lama, jaman orde baru atau jaman reformasi. Terjadi sebuah perdebatan sengit, mengapa begitu? Karena disitu digunakan istilah "baik" dalam kalimat "mana yang lebih baik." Seandainya masalah ini kita memakai istilah "benar" maka kita mungkin akan mudah menyepakati hal-hal penting. Redaksi kalimat yang mungkin tepat adalah mana yang benar antara Indonesia pada kebudayaan jaman orde lama, jaman orde baru, atau jaman reformasi? Seandainya kalimat ini yang dipergunakan, maka sepertinya permasalahan lebih mudah diselesaikan.

Pertanyaannya adalah mengapa menggunakan istilah "baik" bukan istilah "benar"?, inilah permasalahannya: isi kebudayaan ini hampir tidak pernah terpaku pada benar-salah saja atau baik-buruk. Isi kebudayaan sering mengandung paling sedikit dua hal tersebut. ${ }^{26}$ Itulah yang sedang terjadi pada saat ini sehingga kita dibingunkan oleh redaksi tersebut karena pada dasrnya menginginkan kebudayaan yang benar dan sekaligus baik, bila memungkin juga indah.

${ }^{25}$ Ahmad Tafsir, Filsafat Pendidikan Islami, Integrasi Jasmani, Rohani, Dan Kalbu, Memanusiakan Manusia. (Bandung: PT. Remaja Rosda Karya, 2012). 49

26 Ibid. 50 


\section{Implikasi Sistem Nilai Dalam Proses Pendidikan Islam}

Sebuah proses pendidikan memiliki hubungan yang timbal balik dengan sistem nilai dapat kita lihat bagaimana cara pendidik mengambil sebuah keputusan baik secara langsung ataupun tidak langsung. Dari sisi tersebut kita bisa melihat atau bahkan mengetahui nilai-nilai dalam proses pendidikan. Layaknya isi dari sebuah kurkulum, tujuan pembelajaran serta berbagai dimensi lainnya. Hubungan antara nilai dengan sebuah pendidikan bisa dilihat dengan jelas dalam setiap aspek tujuan yang mengandung berbagai macam nilai.

Melalui sebuah proses pendidikan terjadi yang namanya sistem nilai yang hal tersebut membutuhkan transmisi, pewaris, pelestarian serta sebuah pengembangan. Begitupun dengan pelaksanaan pendidikan dibutuhkan sistem nilai untuk kepastian berjalannya sebuah proses pendidikan. Hal ini menjelaskan bahwa eksistensi pendidikan termasuk pendidikan islam adalah sarana vital serta menumbuh kembangkan kreatifitas serta keilmuan siswa, serta melakukan pelestarian terhadap nilai-nilai ilahiyah dan insaniyah serta nantinya diharapkan bisa membeklaisiswa dengan intelektual yang berkualitas dan produktif.

Islam adalah akidah, ibadah, dan sekaligus sistim. Dimana dalam al-Quran dan Sunnah sudah terdapat sarana kebutuhan dan prasarana penerapan untuk menjalankan ajaran islam itu sendiri. Apabila tidak demikian islam hanyalah sebatas teori yang tidak memiliki nilai sama sekali karena hal itu akan ditolak oleh akal pikiran. ${ }^{27}$

Pendidikan Islam memiliki tugas mempertahankan, menanamkan dan mengembangkan fungsi nilai-nilai islam yang berpatokan kepada al-qur'an dan alsunnah. Disebabkan karena adanya modernisasi dalam kehidupan sehari-hari sebagai faktor dari adanya pengaruh serta westernisasi budaya yang sewaktu-waktu bisa memarjinalkan masyarakat islam. Maka pendidikan islam diharuskan memberikan kemudahan serta menumbuh kembangkan nilai-nilainya tanpa melanggar nilai-nilai yang sudah diwahyukan oleh Allah SWT.

Terwujudnya kondisi tersebut diharapkan bisa menjadi sebuah target pengembangan sistem Pendidikan Islam. Oleh karenanya, menurut Mulkhan yang

\footnotetext{
${ }^{27}$ Mohammad Zainal Hamdy, “Telaah Kembali Pemahaman Sistem Ketatanegaraan Dalam Islam ( KHILAFAH ) ( Kajian Historis Dan Ideologis Terhadap Gerakan HTI Di Indonesia )," Syaikhuna: Jurnal Pendidikan dan Pranata Islam 11, no. October (2020): 158-172.
} 
dikutip oleh Siswanto mengatakan bahwa Pendidikan Islam diharuskan membentuk proses yang mengarahkan perkembangan kehidupan dan keberagaman peserta didik menuju kehidupan islami yang sempurna.28 Mempertahankan konsisten serta menyikapi peserta didik sesuai dengan budayanya masing-masing.

Bukan hanya itu, pendidikan islam diharapkan bisa menjadikan nilai etika serta estetika merupakan patokan penting dalam pengembangan Pendidikan Islam. Yaitu dengan menggunakan pendekatan etis dengan estetis, yang artinya semua persoalan bisa dilihat dari berbagai perspektif tanpa meninggalkan nilai-nilai etis islam sebagai idealitas pendidikan islam. Hal ini dapat diperjelas bahwas pendidikan islam berorientasi pada pembentukan peserta didik yang kreatif, berilmu, tawaduk, dan berseni sesuai dengan tuntunan ajaran Islam yang nantinya diharapkan tetap unggul dan diridhoi oleh Allah sampai akhir zaman.

\section{Penutup}

Aksiologi merupakan teori tentang sebuah nilai, manfaat, atau segala hal yang diketahui. Bamel berpendapat bahwa aksiologi ada tiga bagian, yaitu: (1) Moral Conduct, merupakan tindakan moral dan merupakan bidang yang melahirkan disiplin Etika,: (2) Esthetic expression merupakan ekspresi keindahan yang melahirkan disiplin estetika.; dan (3) Socio-political life merupakan kehidupan sosial-politik yang melahirkan filsafat sosial politik.

Aksiologi terbagi mejadi dua, yaitu etika dan estetika. Etika disini terbagi lagi menjadi dua yaitu, etika deskriptif dan etika normatif, begitupun dengan estetika, ada estetika deskriptif dan estetika normatif. Sedangkan Sumber nilai yang berlaku dalam kehidupan manusia dapat dibagi menjadi dua bagian, yaitu, nilai ilahiyah dan nilai Inaniyah.

Karakteristik dan tingkatan nilai juga terbagi mejadi dua yaitu nilai objektif atau subjektif dan Nilai absolute atau berubah. Kaum idealis berpendapat secara yakin tentang tingkat-tingkat nilai yang mana menilai bahwa spiritual lebih tinggi dari pada nilai non spiritual. Karena pada dasarnya, nilai spiritual melahirkan sifat atau perilaku yang santun baik secara nurani hingga akhirnya membawa dampak positif terhadap aspek jasmani seseorang.

${ }^{28}$ Khorofi, “Dimensi Aksiologi Pendidikan Islam.” 13 
Hakikat nilai terdapat poin-poin penting seperti: nilai hidup, nilai nikmat, nilai guna, nilai intelek, nilai estetika, nilai etika, nilai religi. Dalam pembahasan diatas, tujuan pendidikan islam adalah menjadikan peserta didik sebagai manusia yang berkembang kearah yang lebih baik serta menjadi manusia yang beretika dan memiliki kepribadian yang sesuai dengan ajaran islam, baik dari segi spiritual, ilmiah, keilmuan, baik secara individu maupun secara kolektif. Nilai sangat berhubungan dengan pendidikan islam karena pendidikan islam adalah suatu proses pencapaian kesempurnaan dalam hal kemampuan peserta didik sesuai dengan ajaran islam.

Proses pendidikan memiliki hubungan yang timbal balik dengan sistem nilai dapat kita lihat bagaimana cara pendidik mengambil sebuah keputusan baik secara langsung ataupun tidak langsung dari situ kita bisa melihat atau bahkan mengetahui nilai-nilai dalam proses pendidikan. Oleh sebab itu, pendidikan islam memiliki tugas mempertahankan, menanamkan, dan mengembangkan fungsi nilai-nilai islam yang berpatokan kepada al-qur'an dan al-sunnah. 


\section{Daftar Pustaka}

Abadi, Totok Wahyu. “Aksiologi: Antara Etika, Moral.” Kanal (n.d.).

https://ojs.umsida.ac.id?index.php/kanal.

Ali, Mohammad Daud. Pendidikan Agama Islam. Jakarta: Rajawali Press, 2013.

Daulay, Haidar Putra. Pendidikan Islam Dalam Perspektif Filsafat. Jakarta: Kencana Prenada Media Group, 2014.

Dkk, I Dewa Gede. Filsafat Ilmu (Dari Pohon Pengetahuan Sampai Karakter Keilmuan Ilmu Hukum). Malang: Madani, 2014.

Hamdy, Mohammad Zainal. “Telaah Kembali Pemahaman Sistem Ketatanegaraan Dalam Islam ( KHILAFAH ) ( Kajian Historis Dan Ideologis Terhadap Gerakan HTI Di Indonesia )." Syaikhuna: Jurnal Pendidikan dan Pranata Islam 11, no. October (2020): 158-172.

Khorofi, Moh. “Dimensi Aksiologi Pendidikan Islam.” IAIN MADURA, n.d.

Khotimah, Indah Husnul. “Dimensi Aksiologis Pendidikan Islam.” Accessed September 27, 2021. https://www.researchgate.net/publication/329528105.

Mahfud. Mengenal Ontologi, Epistemologi, Aksiologi Dalam Pendidikan Islam. Bawean:

STAI Hasan al-Jufri, n.d.

Ningsih, Elok Setia. “Estetika Dan Pendidikan.” IAIN Kediri, 2014.

Rachmat, Aceng. Filsafat Ilmu Lanjutan. Jakarta: Kencana Prenada Media Group, 2011.

Rohmaniyah, Istighfaratur. Pendidikan Etika, Konsep Jiwa Dan Etika Perspektif Ibnu

Miskawaih Dalam Kontribusinya Dalam Pendidikan Islam. Malang: UIN Maliki Press, 2010.

Salam, Burhanuddin. Logika Materil Filsafat Ilmu Pengetahuan. Jakarta: Rineka Cipta, 1997.

Salim, Agus. “Kajian Tentang Aksiologi Pendidikan Islam.” Last modified 2015. https://isabela-agus.com.

Siswanto. Filsafat Dan Pemikiran Pendidikan Islam. Surabaya: Pena Salsabila, 2017.

Suharto, Toto. Filsafat Pendidikan Islam (Menguatkan Epistimologi Islam Dalam Pendidikan). Yogyakarta: Ar-Ruzz Media, 2014.

Surajiyo. Filsafat Ilmu Dan Perkembangannya Di Indonesia. Jakarta: Bumi Aksara, 2007. - - - Ilmu Filsafat Suatu Pengantar. Jakarta: Bumi Aksara, 2014.

Suriasumantri, Jujun S. Filsafat Ilmu Sebuah Pengantar Populer. Jakarta: Pustaka Sinar Harapan, 1990. 
Susanto, A. Filsafat Ilmu (Suatu Kajian Daam Dimensi Ontologis, Epistimologis, Dan Aksiologis). Jakarta: Bumi Aksara, 2016.

Tafsir, Ahmad. Filsafat Pendidikan Islami, Integrasi Jasmani, Rohani, Dan Kalbu,

Memanusiakan Manusia. Bandung: PT. Remaja Rosda Karya, 2012.

“Kompas." Accessed September 13, 2021. www.kompasiana.com.

“Pengertian-Aksiologi-Aspek-Menurut-Para-Ahli." Accessed September 13, 2021. https://pendidikan.co.id. 